\title{
Marc Loison, Le portrait de Lidoine: des manuels à suivre, des livres à piller
}

\section{Maria Colombo Timelli}

\section{(2) OpenEdition}

1 Journals

\section{Édition électronique}

URL : http://journals.openedition.org/studifrancesi/5231

DOI : 10.4000/studifrancesi.5231

ISSN : 2421-5856

Éditeur

Rosenberg \& Sellier

\section{Édition imprimée}

Date de publication : 1 décembre 2016

Pagination : 500

ISSN : 0039-2944

\section{Référence électronique}

Maria Colombo Timelli, « Marc Loison, Le portrait de Lidoine: des manuels à suivre, des livres à piller », Studi Francesi [En ligne], 180 (LX | III) | 2016, mis en ligne le 01 janvier 2017, consulté le 17 septembre 2020. URL : http://journals.openedition.org/studifrancesi/5231 ; DOI : https://doi.org/10.4000/ studifrancesi.5231

Ce document a été généré automatiquement le 17 septembre 2020.

\section{(c)}

Studi Francesi è distribuita con Licenza Creative Commons Attribuzione - Non commerciale - Non opere derivate 4.0 Internazionale. 


\title{
Marc Loison, Le portrait de Lidoine: des manuels à suivre, des livres à piller
}

\author{
Maria Colombo Timelli
}

\section{RÉFÉRENCE}

MARC LOISON, Le portrait de Lidoine: des manuels à suivre, des livres à piller, in Les Raisons du livre. Du statut de l'œuvre écrite à la figuration du symbole (xiie-xviie siècles), Études réunies par Gérard Gros, Paris, Honoré Champion, 2015, pp. 53-71.

Dans la description de son héroïne, au début de Meraugis, Raoul de Houdenc donne la preuve de ses connaissances rhétoriques et littéraires. En effet, comme le souligne Marc Loison, non seulement ce portrait suit les règles énoncées dans les arts poétiques, mais il se nourrit de l'intertextualité, en particulier par les apports des personnages féminins de Chrétien de Troyes: Enide, Laudine, Fenice. Passage attendu dans le genre romanesque et morceau de bravoure de l'auteur, le portrait de Lidoine peut être considéré comme emblématique de l'art d'écrire et de décrire du XIII siècle. 